\title{
'Ramata': A New Dwarf Variegated Hedychium (Ornamental Ginger) Cultivar
}

\author{
Hamidou F. Sakhanokho², Anthony L. Witcher, Cecil T. Pounders, \\ and James M. Spiers ${ }^{1}$ \\ U.S. Department of Agriculture, Agriculture Research Service, Thad Cochran \\ Southern Horticultural Laboratory, 810 Highway 26 West, Poplarville, MS \\ 39470
}

Additional index words. ginger lilies, Hedychium muluense, somaclonal variation, variegated foliage

Most Hedychium J. Koenig (Zingiberaceae) species have showy and fragrant flowers, which are used in leis and perfumery. Hedychium species are easy to grow and are mostly free of major diseases and pests. The essential oils of some species have been found to have insecticidal, antibacterial, and antifungal activities (Gopanraj et al., 2005; Jadhav et al., 2007; Medeiros et al., 2003). Hedychium plants prefer moist, fertile soil and are considered to be shade plants but will thrive in full sun if provided adequate moisture, and many species will grow and bloom throughout USDA zone 7 (Adams, 1999). Hedychium plants are suitable for landscape use, but their height (up to $2 \mathrm{~m}$ or more) generally limits their use as potted plants. Furthermore, Hedychium plants are well known for the diversity of their flower colors, but their green foliage is mostly uniform and lacks variegation. Only three variegated cultivars, Dr. Moy, Tahitian Flame, and Vanilla Ice, are commercially available. These three cultivars are related in that 'Tahitian Flame', a selection of Terra Nova Nurseries, Inc. (Canby, OR), occurred as a natural branch mutation of 'Dr. Moy' (Korlipara, 2009), and 'Vanilla Ice' is a sport of 'Dr. Moy' selected by Messenbrink's Nursery of Nashville, NC. Developing new dwarf compact cultivars with novel foliar characteristics is a major objective of the Hedychium breeding program at the USDA-ARS Thad Cochran Southern Horticultural Laboratory (TCSHL) in Poplarville, MS. Reported here is Hedychium muluense R.M. Smith 'Ramata', a compact, dwarf $(\approx 71 \mathrm{~cm})$ cultivar with variegated leaves (Fig. 1A). Both dwarfism and variegation are highly desired but rare traits in Hedychium. This is the first report of both of these traits in one Hedychium cultivar.

Received for publication 29 Mar. 2012. Accepted for publication 19 Apr. 2012.

We are greatly indebted to Kermis Myrick, Carrie Witcher, Alex Goins, and Tigest Boutwell for technical assistance.

${ }^{1}$ Retired USDA-ARS scientist.

${ }^{2}$ To whom reprint requests should be addressed; e-mail Hamidou.Sakhanokho@ars.usda.gov.

\section{Origin}

An in vitro assisted breeding program for Hedychium was initiated at the USDA-ARS TCSHL in Poplarville, MS, to increase genetic variation, obtain pre-breeding products of interest (e.g., induced polyploidy), and establish a transformation system. To reach these goals, new in vitro culture protocols, including regeneration through somatic embryogenesis, were established. Seeds were collected from greenhouse-grown $H$. muluense plants. Seed sterilization, germination, and the subsequent tissue culture procedures were performed as described by Sakhanokho et al. (2008). A variegated somaclone plantlet was selected among the regenerated populations derived from somatic embryos of $H$. muluense plants in 2007. The selected plantlet was micropropagated and plants subsequently transferred to the greenhouse at the USDA-ARS TCSHL in Poplarville, MS, where plants were evaluated for 4 years under both greenhouse and outdoor conditions. Plants were also sent to university collaborators at Mississippi State University and Louisiana State University as well as private nurseries in Texas, Florida, and North Carolina for evaluation.

Description and use. The data for morphological traits were derived from 10 random, different plants ( $\mathrm{n}=10$ measurements) chosen at maturity, except for pseudostem and leaf for which the means represent the averages of 10 different plants and three replications for each plant $(\mathrm{n}=30$ measurements). 'Ramata' plants are rhizomatous, herbaceous perennials that reach a height of $71.5 \pm 2.4 \mathrm{~cm}$. Multiple pseudostems are produced from rhizomes, leading to a compact, broad rounded appearance (Fig. 1A). The upright, clumping growth habit results in a plant diameter of $81.2 \pm 4.4 \mathrm{~cm}$. Pseudostem formation is erect and reed-like with an average height of $68 \pm 1.4 \mathrm{~cm}$ and diameter of $3.9 \pm 0.1 \mathrm{~cm}$. Color references throughout this description are made to The Royal Horticultural Society (RHS) Color Chart, fifth edition (RHS, 2007). Pseudostem texture is glabrous, and coloration is yellow-green 144A. 'Ramata' plants are hardy in USDA zones 8 to 10 .
Leaves (Figs. 1A and 1C) are simple and have an oblong lanceolate shape. The leaf arrangement is alternate and distichous. Leaves are $25.4 \pm 0.7 \mathrm{~cm}$ long and $7.6 \pm 0.2 \mathrm{~cm}$ wide. Leaf characteristics include an attenuate apex, a base with clasping sheaths and scarious stipules, an entire margin, and penni-parallel venation. The leaf texture is glabrous on the lower and upper sides. Leaves are medium green, ranging from yellow-green 144A and 144B. Varying widths of creamy white to light yellow variegation (green-yellow 1D, yellowgreen 145D, and green-white 157C-D) are present in the leaves.

Inflorescences (Fig. 1F) form on mature pseudostems as terminal, dense spikes with one to three flowers per bract. Inflorescences have lengths averaging $12.8 \pm 0.3 \mathrm{~cm}$ and widths of $6.2 \pm 0.5 \mathrm{~cm}$. Bracts, which surround the flowers, have yellow-green 144A coloration and average length of $2.0 \pm 0.1 \mathrm{~cm}$ and width of $2.1 \pm 0.0 \mathrm{~cm}$. Flower buds extend from bracts and occur in a range of colors between green (yellow-green 150C and 154C-D) and yellow (yellow-green 5D). Flower bud length, measured from the bract/bud intersect to the bud tip, averages $1.8 \pm 0.2 \mathrm{~cm}$ and width averages $0.4 \pm 0.0 \mathrm{~cm}$. Removal of a mature flower from an inflorescence reveals a bracteole wrapped around the lower portion of a calyx. The longest segment of the bracteole measures $1.7 \pm 0.1 \mathrm{~cm}$ with a width of $0.7 \pm 0.0 \mathrm{~cm}$. Bracteoles have a coloration gradient ranging from yellow-green $145 \mathrm{~A}$ to $145 \mathrm{D}$ with the lighter shade (145D) occurring at the ovary end and the darker (145A) at the upper peak. The calyx of each flower encloses the lower portion of the floral tube. At the longest segment of the calyx, the length is $3.2 \pm 0.0 \mathrm{~cm}$ and width is $0.34 \pm 0.0 \mathrm{~cm}$. Coloration of the calyx has a gradient from the ovary end (lighter, 145D) toward the upper peak (darker, 145A), similar to that of the bracteole.

'Ramata' flowers are zygomorphic and have an average length of $4.7 \pm 0.2 \mathrm{~cm}$ and width of $0.4 \pm 0.0 \mathrm{~cm}$ (length is the measurement from the ovary to labellum tip or the longest segment of the flower). Each flower has a relatively long hypanthium averaging $4.2 \pm 0.1 \mathrm{~cm}$ in length and $0.4 \pm 0.0 \mathrm{~cm}$ in width. The petal-like structures of the flower are actually one highly cleft labellum with multiple lobes (two large lobes and one to three small lobes) and two lateral staminodes. Large labellum lobes are creamy white (yellow group 9D and $8 \mathrm{C}-\mathrm{D}$ ) with a medium yellow (yellow group 13A-C) ridge extending from its base toward the lobe tip. This area has a color gradient in which the yellow is lightest toward the labellum tip and appears darker toward its base at the floral tube. These lobes have an average length of $2.9 \pm 0.1 \mathrm{~cm}$ and width of $0.6 \pm 0.2 \mathrm{~cm}$. Small labellum lobes are $\approx 1.9 \pm 0.1 \mathrm{~cm}$ in length, $0.2 \pm$ $0.0 \mathrm{~cm}$ in width, and have yellow $8 \mathrm{D}$ coloration. Lateral staminodes are creamy white (yellow group 9D and 8C-D) with a medium yellow (yellow group 13A-C) area at the base and middle of the petal-like structure. This area has a color gradient in which the yellow is lightest toward the staminode tip and 

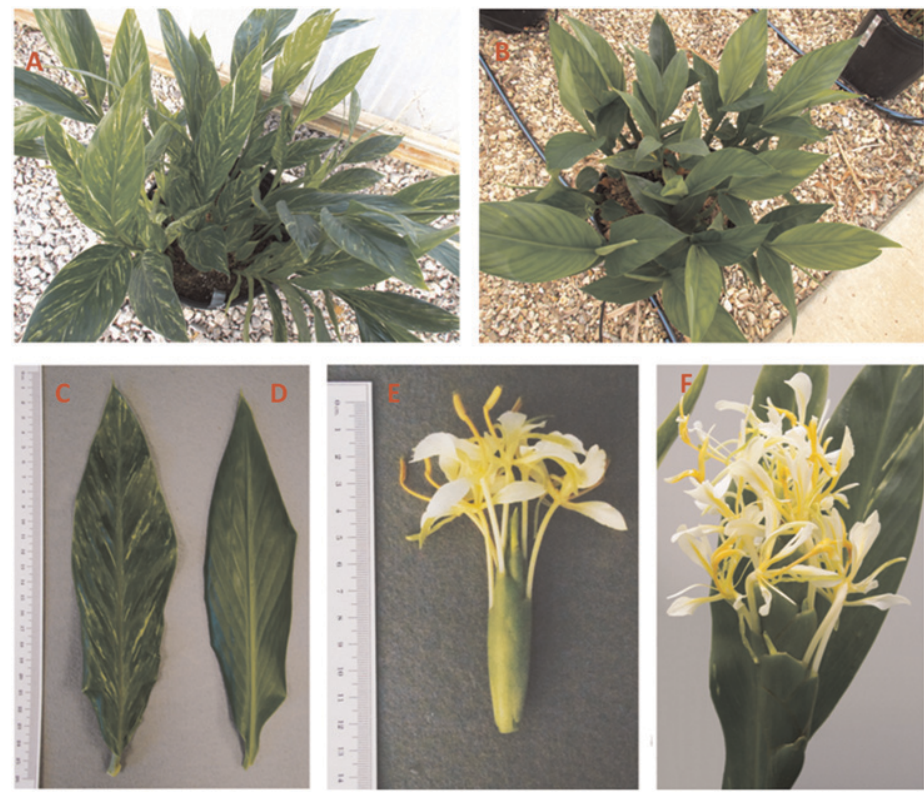

Fig. 1. Comparison of traits between Hedychium 'Ramata' and its parent plant H. muluense R.M. Smith (A-B) Six-month-old H. 'Ramata' (A) plant and 6-month-old H. muluense plant (B). (C-D) Comparison of leaves from $H$. 'Ramata' $(\mathbf{C})$ and $H$. muluense (D) plants. Images are of adaxial surfaces of the leaves. (E-F) Flowers of $H$. muluense $(\mathbf{E})$ and $H$. 'Ramata' plants (F).

appears darker toward its base at the floral tube. Lateral staminodes average $2.2 \pm 0.1 \mathrm{~cm}$ in length and $0.6 \pm 0.0 \mathrm{~cm}$ in width. True petals of the flower are much less showy than labellum and lateral staminode structures and resemble a cross between a typical calyx and petal. Petal coloration is green-yellow 1C, length is $2.8 \pm 0.2 \mathrm{~cm}$, and width is $0.3 \pm$ $0.0 \mathrm{~cm}$. A pistil is present in each flower and includes a stigma, style, and ovary. Pistil length is $\approx 5.7 \pm 0.4 \mathrm{~cm}$. Pistil width is broken down into style width of $0.1 \pm 0.0 \mathrm{~cm}$ and stigma width of $0.2 \pm 0.0 \mathrm{~cm}$. Pistil coloration is yellow $10 \mathrm{~A}-\mathrm{B}$ for the style and yellowgreen 144A for the stigma. Anthers and filament appear to have transformed, resembling petals and are thus termed stamen-like staminodes. There are usually one to four anther structures fused with one filament making up a stamen-like staminode. Unlike the anthers of $H$. muluense, little to no pollen is contained in the mutated anther folds of 'Ramata' (Fig. 1E-F). Stamen-like staminodes are yellow 13A in color. Length measurement is the total length from the area of filament fusion with the floral tube to the tip of the transformed anther/petal-like segment and averages $2.2 \pm 0.1 \mathrm{~cm}$. The width measurement is the width of the petal-like anther segment at its widest point and averages $0.5 \pm$ $0.0 \mathrm{~cm}$. Filament measurement excludes the transformed anther/petal-like segment and has a length of $\approx 1.2 \pm 0.2 \mathrm{~cm}$ and width of $0.1 \pm$ $0.0 \mathrm{~cm}$. 'Ramata' flowers are mildly fragrant and have not been observed to produce seed.

Leaf variegation (Figs. 1A and 1C) in the new cultivar is more uniformly distributed than in 'Dr. Moy' or its two variants, 'Tahitian Flame' and 'Vanilla Ice'. Furthermore, this variegation is very stable. Among the hundreds of plants produced through divisions during the last 4 years, not one plant reverted back to a non-variegated state. In contrast, 'Vanilla Ice' sometimes produces reverted green shoots necessitating periodical removal (Carey and Avent, 2010). Like its parent, H. muluense (Fig. 1B), plants of 'Ramata' (Fig. 1A) can grow on average $71.6 \pm 2.4 \mathrm{~cm}$ tall compared with most Hedychium species and cultivars, which can easily reach 1.5 to $2 \mathrm{~m}$ tall or more. It combines both dwarfism and variegation, two highly desired but rare traits in Hedychium plants. Additionally, a potted 'Ramata' plant produces multiple pseudostems originating from the rhizome, giving it a compact appearance (Fig. 1A). It is well suited to a variety of landscape uses such as a specimen plant, a contrast plant in mixed planters, and in smaller gardens. Like those of the parent plant, flowers of the variegated form are mildly fragrant. This fragrance is not as overpowering as that of some other Hedychium species such as $H$. coronarium J. Koenig.

Nuclear DNA content, genome size, and base pair composition. In an attempt to determine the possible cause(s) of leaf variegation in the new cultivar, several factors were investigated, including nuclear DNA content, genome size, base pair composition as well as chloroplast numbers, stomatal length and width. Nuclei from young leaves collected from five Hedychium 'Ramata' and five $H$. muluense plants were extracted, stained with fluorochromes 4', 6-diamidino2-phenylindole (DAPI) or propidium iodide (PI), and analyzed (minimum 3000 nuclei per sample). Fluorescence ratios, calculated relative to the internal reference Zea mays (cv. CE-777, 2c $=5.43 \mathrm{pg}$ ), were converted to DNA content values and expressed in pictograms (pg) and megabase pairs (Mbp) following the formula: genome size $(\mathrm{Mbp})=$ $\left(978 \times 10^{9}\right) \times$ DNA content $(\mathrm{pg})$ (Doležel et al., 2003; Doležel and Greilhuber, 2010). Base pair composition was calculated following the equation $\mathrm{AT} \%=\mathrm{AT} \%$ for internal standard $\times$ [(fluorescence internal standard, DAPI/fluorescence sample, DAPI) $\div$ (fluorescence internal standard, PI/fluorescence sample, PI) $]^{(1 / \text { binding length) }}$ (Godelle et al., 1993), where AT\% of the internal standard, Zea mays $=51.1 \%$, and binding length of DAPI $\approx 3.5 \mathrm{bp}$ (Meister and Barrow, 2007). Data for nuclear DNA content, genome size, and base pair composition as well as for chloroplast numbers and stomatal length and width were analyzed using SAS software (Version 9.3; SAS Institute Inc., Cary, NC), and differences between means were determined according to Student's $t$ test $(P \leq$ $0.05)$. No significant differences $(P \leq 0.05)$ were found between the new cultivar Ramata and the original plant for nuclear DNA content, genome size, and base pair composition. The mean DNA content, genome size, and AT $\%$ for $H$. 'Ramata' were $2.1 \mathrm{pg}, 2049.9 \pm$ $3.4 \mathrm{Mbp}$, and $46.9 \% \pm 0.1 \%$, respectively, and those for H. muluense were $2.1 \pm 0.0 \mathrm{pg}, 2047.3$ $\pm 7.1 \mathrm{Mbp}$, and $46.7 \% \pm 0.1 \%$, respectively. Leaf variegation in 'Ramata' is highly stable, suggesting this variegation is likely of periclinal origin.

Chloroplast numbers and stomatal length and width. Sections of fresh leaves were obtained and prepared for fluorescent microscopic observation of guard cells and chloroplasts. A scalpel blade was used to gently shave away most of the pigmented upper part of the leaf to make the guard cells and thus chloroplasts on the bottom portion of the leaf more visible. The slivered leaf was trimmed to $\approx 0.5$ to $1.5 \mathrm{~cm}^{2}$ and placed on a microscope slide. Enough water was added to cover the sample, and a coverslip was applied. The sample was immediately observed under the microscope to avoid its drying, which could damage the guard cells. The sample will burn when left in the illumination path for too long, so focusing as well as locating guard cells for photographing was done quickly. For each $H$. 'Ramata' and $H$. muluense, two leaves were collected from three separate plants. Two preparations were made for each leaf resulting in 12 separate preparations to evaluate for each genotype. The preparations for each plant were photographed, and the chloroplasts were counted and measurements were made of the guard cells (both length and width). The length and width measurements were made at the widest and longest locations on the guard cells. An Olympus BX60 (Olympus America, Inc., Center Valley, PA) with a fluorescent cube, an attached Olympus DP72 camera, and an Olympus BH2-RFL-T3 lamp source was used. Measurements were completed with DP2-BSW software. There was no significant difference between the two genotypes for chloroplast numbers, but the stomata of the parent plant were significantly longer and wider than those of 'Ramata'. The mean chloroplast number, mean stomatal length, 
Table 1. Shoot number per plant, plant height, average shoot circumference per plant, shoot dry weight, and substrate $\mathrm{pH}$ for Hedychium muluense 'Ramata' plants grown in three substrates.

\begin{tabular}{|c|c|c|c|c|c|c|}
\hline Substrate $^{z}$ & $\begin{array}{l}\text { Shoots } \\
(\text { no. })^{\mathrm{x}}\end{array}$ & $\begin{array}{l}\text { Plant ht } \\
(\mathrm{cm})^{\mathrm{x}}\end{array}$ & $\begin{array}{c}\text { Shoot } \\
\text { circumference }(\mathrm{cm})^{\mathrm{x}}\end{array}$ & $\begin{array}{c}\text { Shoot } \\
\text { dry wt }(\mathrm{g})^{\mathrm{x}}\end{array}$ & $\begin{array}{l}\text { Substrate } \mathrm{pH} \\
\left(0 \mathrm{DAP}^{\mathrm{y}}\right)^{\mathrm{x}}\end{array}$ & $\begin{array}{l}\text { Substrate } \mathrm{pH} \\
(100 \text { DAP })^{\mathrm{x}}\end{array}$ \\
\hline$\overline{\mathrm{PB}}$ & $4.0 \mathrm{a}$ & $37.3 \mathrm{a}$ & $3.02 \mathrm{a}$ & $26.7 \mathrm{a}$ & $6.08 \mathrm{a}$ & $6.14 \mathrm{a}$ \\
\hline PM:P & $5.0 \mathrm{a}$ & $32.9 \mathrm{a}$ & $2.80 \mathrm{a}$ & $25.0 \mathrm{a}$ & $4.51 \mathrm{c}$ & $4.31 \mathrm{~b}$ \\
\hline PM:PB:P & $4.7 \mathrm{a}$ & $37.4 \mathrm{a}$ & $2.94 \mathrm{a}$ & $27.2 \mathrm{a}$ & $4.80 \mathrm{~b}$ & $4.15 \mathrm{~b}$ \\
\hline
\end{tabular}

${ }^{\mathrm{z}} \mathrm{PB}=$ pine bark; $\mathrm{PM}: \mathrm{P}=3$ peatmoss: 1 perlite; $\mathrm{PM}: \mathrm{PB}: \mathrm{P}=3$ peatmoss: 2 pine bark: 1 perlite.

${ }^{\mathrm{y}} \mathrm{DAP}=$ days after planting.

${ }^{\mathrm{x}}$ Means ( $\mathrm{n}=10$ for shoot numbers, plant height, shoot circumference, and shoot dry weight; $\mathrm{n}=4$ for substrate $\mathrm{pH}$ ) followed by different letters within columns indicate significant difference at $P<0.05$ using the Tukey-Kramer honest significant difference test.

and mean stomatal width for 'Ramata' were $23.0 \pm 0.7,33.0 \pm 1.0 \mu \mathrm{m}$, and $22.3 \pm 0.4 \mu \mathrm{m}$, respectively, and those for $H$. muluense were $23.4 \pm 0.5,38.8 \pm 0.7 \mu \mathrm{m}$, and $23.7 \pm 0.3 \mu \mathrm{m}$, respectively.

Performance. Growth characteristics of H. muluense 'Ramata' were evaluated in three container substrates in a shaded greenhouse with maximum irradiance of 370 $\mu \mathrm{mol} \cdot \mathrm{m}^{-2} \cdot \mathrm{s}^{-1}$ in a natural photoperiod and a temperature range of 19 to $35^{\circ} \mathrm{C}$. Substrates included pine bark (PB), 3 peatmoss: 1 perlite (PM:P), and 3 peatmoss:2 pine bark: 1 perlite (PM:PB:P), all amended with $5.33 \mathrm{~kg} \cdot \mathrm{m}^{-3} 18 \mathrm{~N}$ 2.6P-10K (Harrell's 8-9 months; Harrell's LLC., Lakeland, FL) and $1.77 \mathrm{~kg} \cdot \mathrm{m}^{-3}$ dolomitic limestone. In July 2011, single rhizome divisions were transplanted into $6.0-\mathrm{L}$ plastic containers (C600; Nursery Supplies Inc., Kissimmee, FL) filled with substrate and placed on a bench in a greenhouse with $50 \%$ shade. The experiment was arranged in a randomized complete block design with 10 replications per substrate, and plants were irrigated as needed determined by container weight. The experiment was ended at $100 \mathrm{~d}$ after planting (DAP) and data collection included shoot number per plant, plant height, average shoot circumference per plant, and shoot dry weight, whereas substrate $\mathrm{pH}$ was analyzed at experiment initiation and termination. Data were analyzed with analysis of variance using JMP Version 8 (SAS Institute Inc., Cary, NC), and differences between treatment means were determined using the
Tukey-Kramer honest significant difference test $(P<0.05)$.

All rhizomes exhibited new shoot growth by 31 DAP, overall ranging from one to nine shoots per plant at 100 DAP. Among substrates, there were no significant differences in shoot number per plant, plant height, average shoot circumference per plant, or shoot dry weight at 100 DAP (Table 1). Variation in plant growth was observed within each substrate, yet did not lead to any differences between substrates. Substrate $\mathrm{pH}$ differed among all substrates at 0 DAP, was similar between PM:P and PM:PB:P at 100 DAP, and overall ranged from 4.1 to 6.4 at 100 DAP. Nevertheless, plants did not exhibit any negative visual signs associated with substrate $\mathrm{pH}$. Overall, H. muluense 'Ramata' performed well in all three substrates and within a wide $\mathrm{pH}$ range, suggesting that this plant can readily adapt to a wide range of soil types.

A patent application has been submitted to the U.S. Patent and Trademark Office. Inquiries regarding licensing may be addressed to: Coordinator, Technology Licensing Program, USDA, Agricultural Research Service, Office of Technology Transfer, 5601 Sunnyside Avenue, Beltsville, MD 207055131; phone: (301) 504-5989. Plants for research purposes may be obtained directed from the senior author.

\section{Availability}

\section{Literature Cited}

Adams, R.S. 1999. Propagation and cultivation of selected gingers in north Florida. Proc. Fla. State Hort. Soc. 112:114-115.

Carey, D. and T. Avent. 2010. Hedychium-Ginger lilies for the garden. 12 Sept. 2011. <http:// www.plantdelights.com/Hedychium-GingerLilies-for-the-Garden/products/735/>.

Doležel, J., J. Bartoš, H. Voglmayr, and J. Greilhuber. 2003. Nuclear DNA content and genome size of trout and human. Cytometry A 51A:127-128

Doležel, J. and J. Greilhuber. 2010. Nuclear genome size: Are we getting closer? Cytometry A 77A:635-642.

Godelle, B., D. Cartier, D. Marie, S.C. Brown, and S. Siljak-Yakovlev. 1993. Heterochromatin study demonstrating the non-linearity of fluorometry useful for calculating genomic base composition. Cytometry 14:618626.

Gopanraj, G., M. Dan, S. Shiburaj, M.G. Sethuraman, and V. George. 2005. Chemical composition and antibacterial activity of the rhizome oil of Hedychium larsenii. Acta Pharm. 55:315320 .

Jadhav, V., A. Kore, and V.J. Kadam. 2007. In-vitro pediculicidal activity of Hedychium spicatum essential oil. Fitoterapia 78:470 473.

Korlipara, H. 2009. Hedychium plant named 'Tahitian Flame'. US PP19,921 P2.

Medeiros, J.R., L.B. Campos, S.C. Mendonça, L.B. Davin, and N.G. Lewis. 2003. Composition and antimicrobial activity of the essential oils from invasive species of the Azores, Hedychium gardnerianum and Pittosporum undulatum. Phytochem. 64:561-565.

Meister, A. and M. Barrow. 2007. DNA base composition of plant genomes, p. 177-185. In: Doležel, J., J. Greilhuber, and J. Suda (eds.). Flow cytometry with plant cells: Analysis of genes, chromosomes and genomes. WileyVCH, Weinheim, Germany.

Royal Horticultural Society. 2007. The Royal Horticultural Society's colour chart. 5th ed. Royal Hort. Soc., London, UK.

Sakhanokho, H.F., R.Y. Kelley, and K. Rajasekaran. 2008. First report of plant regeneration via somatic embryogenesis from shoot apexderived callus of Hedychium muluense R. M. Smith. J. Crop Improv. 21:191-200. 